\title{
Gendered Representations of Male and Female Social Actors in Iranian Educational Materials
}

\author{
Amir Ghajarieh $^{1} \cdot$ Ali Salami ${ }^{2}$
}

Published online: 31 March 2016

(C) Springer Science+Business Media New York 2016

\begin{abstract}
This research investigates the representations of gendered social actors within the subversionary discourse of equal educational opportunities for males and females in Iranian English as a Foreign Language (EFL) books. Using critical discourse analysis (CDA) as the theoretical framework, the authors blend van Leeuwen's (Texts and practices: Readings in critical discourse analysis, Routledge, London, 2003) 'Social Actor Network Model' and Sunderland's (Gendered discourses, Palgrave Macmillan, Hampshire, 2004) 'Gendered Discourses Model' in order to examine the depictions of male and female social actors within this gendered discourse. The gendered discourse of equal opportunities was buttressed by such representations within a tight perspective in proportion to gender ideologies prevailing in Iran. Resorting to CDA, we can claim that resistance against such gendered discourse in Iranian EFL textbooks militates against such gender norms. These representations of male and female social actors in school books are indicative of an all-encompassing education, reinforcing that the discourse of equal opportunities is yet to be realized in the education system of Iran.
\end{abstract}

Keywords CDA $\cdot$ Discourse $\cdot$ Educational materials $\cdot$ Gender $\cdot$ Iran

The 'equal opportunities' discourse views men and women "as different but endowed them with the right to engage in pursuits traditionally performed by the opposite sex if they so desire" [17, p. 143]. As Davies [9] observes, the discourse of 'equal opportunities' cannot be considered an effective discourse, given that such a

Amir Ghajarieh

amirbiglarbeigi@yahoo.com

1 Faculty of Languages and Linguistics, University of Malaya, Kuala Lumpur, Malaysia

2 Faculty of Foreign Languages and Literatures, University of Tehran, Tehran, Iran 
discourse fails to challenge the dichotomy of men and women and conflicts other inequality discourses in different settings.

Such discourse has been approved in the legal document of many countries [40]. Particularly, in the case of Iran where the focus of this study lies, Iranian laws hold education accountable for the support of girls' social and political status [30]. Many government reports including The 2001 National Report on Women's Status in the Islamic Republic of Iran, published by the Centre for Women's Participation, Office of the President, emphasize gender equality in education and require the Iranian Ministry of education to modify educational materials in order to present a genderneutral picture of women [6].

Given the importance of school textbooks among varied agencies in education [5], this study seeks to explore whether the subversive gendered discourse of equal opportunities in male and female education as the subordinate discourses to the discourse of equal opportunities has been given sufficient backing in Iranian English as a Foreign Language (EFL) educational materials at secondary, high school and pre-college levels. After all, teaching English in Iran starts at the secondary level and this continues for 7 years before students get their diplomas.

As many occupations have been traditionally gendered and were deemed more appropriate for one gender rather than another [51], this area is also significant in gendered discourses. Drawing on Weatherall's [50] and Sunderland [40] identifies the existence of the 'equal employment opportunities' discourse within the discussion of gender and employment opportunities. Following the second wave feminism, equal job opportunities for both men and women were emphasized [37]; however, the equal opportunity discourse in reality contradicts the practical considerations of discourse. Sunderland [40] asserts that many social considerations and limitations could hinder equal employment opportunities for men and women.

Meanwhile, the discourse of 'equal education opportunities for men and women' supports the notion that education should be for both boys and girls, and they should have equal access to educational resources. The discourse of 'equal education opportunities' was initially encouraged by many educational institutes in the UK and the USA and "had implications for language classroom as well as for issues such as access" [40, p. 82]. The discourse of equal opportunities in education is closely linked to the discourse of equal opportunities, and the support of this discourse depends on social and cultural considerations [40].

\section{Education, Culture and Societal Change of Norms}

The Iranian schooling system in Iran consists of four tiers, namely primary, secondary, high school and pre-university. Educational materials are provided by the Ministry of Education. Given the fact that textbooks are regarded as societal artifacts, it is of significance to incorporate cultural aspects in the Iranian society. In fact, Iranian culture is propounded affected by Islamic tradition, ancient Persian and western cultures. Nonetheless, under the Iranian law, people are obliged to abide by Islamic traditions and rules [18, 34]. 
Under the Sharia law dominating Iran, females should "cover up everything but their face and hands with a hijab" [38, p. 96]. With regard to hijab, even though there was no Islamic or national dress for women in Iran, after the Islamic Revolution "the overcoat and maqna'eh [a type of headscarf] were introduced for women, whereas for men beards were encouraged and neckties were frowned on and forbidden in public places" [31, p. 305]. Interestingly, these dress codes for men and women differ for people from ethnic minorities and those living in the rural areas [31].

Likewise, with regard to family roles under the Sharia, males are regarded as the sole breadwinners of their families and should provide for their spouses and children [35]. Although women in Islam are not required to carry out the house chores [8], this is a way of almost every family in Iran [15]. The bipartition of work spaces for both sexes in this way may be traced in the core of male hegemony which has prevailed in Iran from ancient Persian. The Islamic rule of male/breadwinner together with the tradition of female/at home corresponds to patriarchal beliefs and gender ideologies dominating numerous traditional families [32], and such rules reinforce patriarchal gender roles for both men and women.

Another significant development which has come into existence since the inception of the Islamic Republic included that alcohol consumption be banned for being 'haram' in Islam [33]. "Haram is an Islamic term indicating what is not allowed for Muslims" [33, p. 76]. Public drunkenness is punishable by Islamic law and people are jailed for this sin [28]. Furthermore, the Iranian culture does not allow for free relationships between men and women. Before the establishment of Islamic Republic of Iran, the norms were regarded as secular without any particular attention to Islam as the dominant religion of the majority of Iranian populace. In the era during the Shah of Iran, societal norms supported more Western ideologies in Iranian society with little care to manifestations of Islam, including Hijab and other Islamic laws. Such norms were also reinforced before and after the Islamic Revolution in Iran.

\section{How Gender is Represented in Iranian Context}

A number of studies were carried out in the Iranian context to identify gender stereotypes in school educational materials from 1987 to 1994 (see, e.g., [16, 23, 44]. Two major studies have been carried out recently on the Iranian linguistic study of sexism. First, in a study on the subliminal effect of sexism on EFL learners, Babaii and Ansary [1] concluded that sexist attitude exists in two EFL textbooks designed for Iranian secondary-level students. This study was purely quantitative and adopted a non-discourse approach to analyzing gender.

In a more recent case of Iranian linguistic study of sexism, two major studies have been carried out. First, Babaii and Ansary [1] concluded in a study on the subliminal effect of sexism on EFL learners that sexist attitude exists in two EFL textbooks designed for Iranian secondary-level students.

In Babaii and Ansary's [1] study, the focus was mainly on women's rights and the degree of their suffering instead of the idea of equality between men and 
women. Hamdan and Jalabneh [21, para. 3] clearly emphasized that Babaii and Ansary's [1] study was in pursuit of proving male dominance over females when he explicitly stated that Babaii and Ansary's [1] research "paid maximum attention ...to the question of male and female dominance" (p. 52). Additionally, the publication year of the EFL textbook analyzed in Babaii and Ansary's [1] study dates back to 1999, and no other study of this type has focused upon EFL textbooks published recently in Iran, particularly after the addition of one EFL textbook to the secondary level and the complete modification of the EFL textbook at the preuniversity level.

In the case of Babaii and Ansary's [1], apart from being a rather out-dated argument regarding gender differences stemming from Thorne and Henley's [43] work nearly two decades ago, dominance theory as Holmes [24] suggests cannot be fruitful when considering different settings in which power is not exerted through gender. Dominance theory does not account for cultural differences. As Goddard and Mean [19] maintain, there are many cultures in which interrupting one's interlocutor is a competitive factor performed by men and women concurrently. Assuming that some discourse features might be attributed to males in certain cultures, it is erroneous to generalize this assumption to different cultures and societies.

Thus, it is clear from this line of argument that Babaii and Ansary's [1] study by adhering to the dominance theory which cannot hold against its critiques did not account for many cultural and individual differences. It was also not in line with the latest trends in gender studies. Based on the latest theories of difference between men and women, femininity and masculinity are not bipolar. There are degrees of masculinity and femininity, and the type of hegemonic masculinity backed up by the widely held beliefs and ideologies of society can be held responsible for the differences and discrimination between men and women [19].

A second major study on Iranian educational materials was conducted by Paivandi [34] in which he analyzed 95 school textbooks published under the supervision of Iranian Education Ministry. In this research, he concludes that discrimination and biases inherent in Iranian textbooks can be attributed to the Islamic worldview of such textbooks. While his study reveals an important feature of Iranian textbooks in general, it lacks a linguistic slant and he did not analyze gender and women rights as the main focus of his study. Moreover, he discovered biases in general-not focusing solely on gender biases-with figures and failed to analyze his data qualitatively.

As for being representative in Iranian education system, Iranian EFL textbooks can serve as the ample cases to be focused on in this study, given that such educational materials strive to capsulate and instruct Islamic and Iranian values through the medium of English. As such these series of textbooks, comprising 7 course books ( 3 at secondary level 1 at high school and 1 at pre-university levels), were included for the purpose of the study. On the contrary, other textbooks, including science and mathematics, designed for various levels of Iranian schools have been written in Persian and may not quite fit into our analysis of textbooks written in English. Besides, other Iranian textbooks have been authored for the Persian audience, while EFL textbooks may highlight Iran's cultural and social 
values for those wishing to learn a new culture. Such situation can further reinforce traditional beliefs and shape conflates concepts regarding cultural values of English as a global language in the learner's mind.

\section{Theoretical Background of this Study}

This research is grounded in the critical discourse analysis (CDA) approach. Based on this intellectual paradigm, language is a social practice [14] and the context in which language occurs plays a fundamental role in CDA. Issues of primary concern to CDA are those having the potential to discursively circulate power and ideology; gender is one of these issues that CDA could explore [52, 53]. Further, Wodak [53] and van Dijk [47] underline that CDA is prompted by social problems. As Sunderland [40] notes, "the social issue and dramatic problem [in gender studies] is gender-an issue and often a problem for women and girls; in different ways, for men and boys; and accordingly for gender relation" (p. 10). Given that gender biases can be one of our social problems, CDA could theoretically be an apt tool to analyze gendered discourses.

The marginalization of different minority groups and the underpinning of power imbalance in text and talk is part of social practice to construct and maintain the status quo of powerful groups in text $[10,13]$. Through this subliminal tool, powerful groups ensure their dominance over other groups including women [29]. Given that CDA reveals ideologies disseminated, constructed, naturalized and legitimized through text and talk by powerful groups having access to language resources (Fairclough [11, 12], critical discourse analysis could reveal gender ideologies disseminated and legitimized through text and talk as well.

Another line of debate for adopting CDA is that CDA focuses on text analysis to explore power, ideology and identity. "CDA is about examining discourses and the construction of knowledge, power and identity through the close analysis of language texts. CDA analyzes language in use, to demonstrate how discourse systematically constructs versions of the social world and positions subjects in relations of power, with political consequences" [7, p. 190]. Considering the fact that our present focus is analyzing in texts and images intimately associated with the texts of Iranian EFL textbooks, CDA should be quite conducive on this score.

\section{Analytical Frameworks}

CDA has no single unified theoretical methodology [25, 29, 46]. Whereas the present study is grounded in CDA, this study requires detailed models of analysis in order to explore the interplay between CDA, gender, identity and education. To answer these research questions, this study fused two models of analysis: the 'Social Actor Network Model' proposed by van Leeuwen [48] and the 'Gendered Discourses Model' proposed by Sunderland [40].

The reason for fusing these two models lies in the fact that these two models enable a multi-layered rather than a monolithic perspective in analyzing the data. 
This is in line with the CDA principle that a triangulatory approach in CDA could be more fruitful rather than a single unified model of analysis [53]. In the subsequent sections, the models of analysis adopted to answer the research questions in this study will be elaborated.

\section{Sunderland and Gendered Discourses Model}

Sunderland [40] proposed a model to ascertain and label various gendered discourses produced in a text. With a gender focus in mind, her model stresses the representations of male and female social actors through gendered discourses in text [40]. This model embraces the CDA definition of discourse as being constitutive and applies feminist theories to further the study of language and gender.

The intriguing notion regarding Sunderland's model is that naming discourses could yield a deeper analysis of discourse at the meso level. Further to that, identifying the type and function of discourses through this model sheds more light on how each instance of discourse constructs, reiterates, or subverts ideology and social power at the macro level. In order to examine how gendered discourses are supported or resisted in the text, Sunderland [40] examines what lexical and grammatical items are chosen among all choices available to text-producers within a gendered discourse.

\section{Van Leeuwen's 'Social Actor Network Model'}

For the purpose of this study, CDA will serve as the theoretical background. In this section, Van Leeuwen [48] theoretical framework will be explained as a potential model to analyze gender within the paradigm of CDA.

Based on van Leeuwen's [48] model, the textual representation of social actors is categorized as "deletion (systems 1 and 2), rearrangement (systems 3-5), and substitution [systems 6-22]" (p. 67). In his model, "deletion involves voice, and also nominalization and adjectivalization, rearrangement principally involves transitivity, while substitution is initially realized by aspects of the structure of the nominal group" (p. 67).

As one type of discourse (here EFL textbooks) does not encompass all the categories of social actor representations delineated by van Leeuwen [48], only certain features of van Leeuwen's [48] model will be examined to examine the representation of male and female social actors within gendered discourses. More specifically, in the case of exclusion, we will investigate suppression and backgrounding, and in the case of inclusion and role allocation, we will analyze individualization, nomination, functionalization and differentiation.

Moreover, van Leeuwen did not mention pronouns as a type of individualization and substitution because his model initially examines social actors in terms of immigration.

Henceforth, we would like to include feminine pronouns and masculine pronouns as a hybrid subcategory of individualization and substitution in our analysis of 
Iranian EFL textbooks. It is notable that the plural pronouns of you/your, we/our and they/their do not fall in this category, for these pronouns have the characteristic of substitution. However, they may assimilate male and female social actors in text representations. This also holds true in the cases of the pronouns I/my/me and you/ your. They have the characteristic of substitution; nevertheless, they may not reveal the identity of social actors as males or females. As van Leeuwen [48] notes, these representations categorize social actors based on identity.

Furthermore, the possessive pronouns, my, your, etc., are realized under the class of categorization through physical and relational identification. As van Leeuwen [48] notes, relational and physical identifications 'typically... are possessivated... by means of a possessive pronoun ['her friend'].' This extension of van Leeuwen's [48] 'Social Actor Network Inventory' proposed by this study could be beneficial for other researchers examining gender representations with the aid of van Leeuwen's [48] theoretical model.

\section{Research Questions}

The following research questions are proposed to examine the gendered discourse of equal opportunities in education for men and women in Iranian EFL textbooks at different educational levels.

RQ1 How is this discourse resisted or supported in the texts Iranian EFL textbooks at different educational levels?

RQ2 How does this gendered discourse reflect ideological assumptions on gender in Iranian society?

\section{Methodology}

This study has analyzed seven Iranian EFL textbooks at the secondary, high school and pre-college levels. This series of textbooks serves as the corpus of the present research. Right path to English I, II, III by Birjandi and Soheili [2]; English 1, 2 and 3 by Birjandi et al. [3]; English 1 and 2- pre-university level by Birjandi et al. [4]. Tehran: Ministry of Education, Centre for the Publication of University Textbooks.

The authors first analyzed the textbooks using Nvivo9 software to gain a better understanding of recurring patterns in the data with regard to the discourse and equal opportunities. To triangulate the data, numeric evidence is also provided alongside the qualitative analysis of the textbooks. Since Iranian EFL textbooks seek to teach English with a special focus on Iranian culture as the one that all Iranian students should respect and learn, these textbooks can be considered as a kaleidoscope of school textbooks taught in Iranian schools. 


\section{Data Analysis}

\section{Discourse of Equal Education Opportunities for Men and Women Through Functionalization in Lexis}

According to van Leeuwen [48] inventory, in the analyzed textbooks, a large number of male and female social actors were individualized and functionalized as students in lexis (84 cases: 40 for secondary-level textbooks, 29 for high schoollevel textbooks and 15 for pre-college textbooks). Following are sample sentences from EFL textbooks used for different educational levels in Iran.

Sample High school, Book I p. 5

A My name is Bahram. I'm a student. I'm 15 years old.

Sample Secondary level, book II, p.76

B Mary is a student.

Sample High school, Book 1, p. 22

C My students are clever. They learn very fast. (In the picture, a group of male students are featured)

Sample High school, Book III, p. 22

D My brother can tell you the names of the students in his class. (A male social actor was functionalized as a student and attributed to a group social actors subsumed under the general heading of 'a group of students')

Sample High school, Book III, p. 59

E What does the teacher want her student to do?

Sample Pre-college level, p. 18

F Maryam is a good student.

Sample High school, Book III, p. 75

$\mathrm{G} \quad \mathrm{He}$ is a good student.

These representations of male and female social actors in samples A and B support the discourse of 'equal opportunities in education for men and women.' The underpinning of this discourse is progressive in the case of women [26]. Nonetheless, no female actors were functionalized as college students in the educations materials which have been analyzed. This is indicative of the fact that this pro-women discourse was supported within a limited range.

Despite the fact that no male characters were individualized and functionalized as college students in the analyzed textbooks, they were individualized through masculine pronouns (he) and functionalized as perspective college students. Following is an instance:

He is working hard. He wants to go to university. He plans to study physics. I think this is a good end (High school level, Book III, p. 23).

As van Leeuwen [48, 49] maintains, individualization is an important feature in realization of social actors and those social actors who were not individualized may lose the identification of the reader and this may exclude some social actors and obscure realities regarding those social actors who were not individualized in texts 
[48, p. 46]. Sunderland [40] also highlights the importance of individualization of male and female social actors in the spheres from which they were traditionally excluded. The lack of nomination and individuation of female social actors as university students resist the 'equal education opportunities for men and women,' based on Sunderland's [40] 'Gendered Discourses Model.'

Besides, female social actors functionalized as students were not assimilated as a group of students studying together with male students in lexis, based on van Leeuwen's [48] model. The accompanying images closely related to the texts also featured male and female students as separate groups.

This notion indicates that the functionalization of male and female social actors was defined only within a narrow perspective in line with the notion that women and men should be separated in public places, including educational settings [20].

As Sunderland [40] notes, there are many discourses impinging on one discourse in the representations of male and female social actors. One can consider another traditional gendered discourse in relation to the discourse of 'equal education opportunities.' This is the traditional discourse of 'Women marginalization in sciences, technology and medicine.' Based on Sunderland's [40] 'Gendered Discourses Model,' these two gendered discourses hold oppositional relations with one another. Furthermore, female social actors were not individualized and functionalized in high-level jobs. Male social actors were represented in 89 cases as engineers, bus drivers, policemen, scientists and doctors, while their female counterparts were represented solely as a dentist as a boss in just one case each. In other words, females were not represented whatsoever in male-nominated and/or high-level occupations of engineers, bus drivers, policemen, scientists and doctors.

For instance, in the textbooks under study, male social actors were individualized and functionalized as computer engineers, doctors and scientists. Following are some sample texts representing male social actors in these professions.

1. Mr. Amini is a doctor (secondary level, Book II, p. 1).

2. Even though he was a computer engineer, he didn't know how to fix the computer (Pre-university level textbook, p. 70).

3. Thomas Edison is one of the most important scientists and inventors of the past two centuries (Pre-university level textbook, p. 74).

4. The Italian scientist, Galileo was the first person who used this invention.

5. He is a dentist (High school level, book II, p. 43).

6. Isaac Newton was a great scientist (High school level, Book I, p.73).

According to van Leeuwen's [48] model, the functionalization of male social actors as scientists, computer engineers, doctors and dentists backgrounds the previous functionalization of these male social actors as college students who majored in the fields of science, computer, medicine and dentistry.

Based on Sunderland's [40] model, these representations support the discourse of 'Women's marginalization in sciences, technology and medicine' and resist the discourse of 'equal education opportunities for both men and women.' Grounded on van Leeuwen's [48] model, one can argue that these representations exclude female college students majoring in science, computer engineers, medicine and dentistry. 
As Stange et al. [39] note, women have always been excluded from science and technology institutes. Additionally, Pololi [36] reports women are marginalized in the field of medicine. In this regard, Iran is no expectation; for instance, in 2012 they were banned from 77 college majors, including some majors related to the fields of science and technology [41]. Or in the case of the medicine filed, universities were mandated following the year 2006 to allocate fewer numbers of seats to female applicants [22]. Thus, based on van Leeuwen's [48, 49] and Sunderland's [40] assertions, the exclusion of women in the fields related to science, technology and medicine obscures the realities regarding discrimination and mental harassment of the female college students of these majors in Iran.

Based on van Leeuwen [48], one can argue that these social actors were excluded from the representations of male and female social actors in Iranian EFL textbooks. Based on van Leeuwen [48] and Sunderland [40], this could obscure the reality regarding the existence of such gender identities in Iran. The exclusion of such gender identities may also lead to overlooking the fact that these people are arguably discriminated in Iran. As Taxel [42] holds, distorted representation of reality may convince the read that the excluded identities and groups are not important. The resistance against the discourse of equal education opportunities for men and women in Iranian EFL textbooks show inclusive education has yet to be achieved in the education system of Iran.

\section{Conclusion}

This study confirms Sunderland's [40] claim that the discourse of 'equal opportunities' should be accompanied with other gendered discourses with the purpose of protecting educational opportunities for girls. As for Iran, the discourse of equal opportunities in education should be highlighted along with other subversive gendered discourses. For instance, Iran still considers "household and childcare as women's primary responsibility" [45, p. 115]. As such, no matter how many girls are enrolled for schools in Iran or how many women graduate from colleges each year, the dominant discourses of femininity and masculinity still compete with the pro-women discourse of 'equal opportunities.' A similar situation can be traced in other countries where gender ideologies supported by religious and cultural beliefs are still prevalent.

Theoretically speaking, "textbooks are developed on the basis of written curriculum... [and] textbooks constitute[s] an intermediate stage between the intended (written) curriculum and the implemented curriculum" [27, p. 170]. Hence, school educational materials can mirror curricula used in the education systems of many countries. Resistance against the discourse of equal education opportunities in the Iranian EFL textbooks at different educational levels as an alternative gendered discourse to the discourse of equal opportunities indicates that curriculum designers and textbooks writers need to accord remarkable attention to the policies, school textbooks and material existing in the education system of a given country. If we aspire to advance our education system with the significant policy of inclusive education, this study suggests our textbooks should be 
constructed sensitively to other subversive discourses alternative to the 'equal opportunities' discourse. This could highlight gender, sexuality, race, ethnicity, religion and other individual differences in education, and future studies in the field of education and identity can explore these possibilities.

\section{References}

1. Babaii, E., \& Ansary, H. (2003). Subliminal sexism in current ESL/EFL textbooks. Iranian Journal of Applied Linguistics, 6(1), 40-56.

2. Birjandi, P., \& Soheili, A. (2011). Right path to English I, II, III. Iran: Ministry of Education, Centre for the Publication of University Textbooks.

3. Birjandi, P., Noroozi, M., \& Mohmoodi, G. (2011). English 1, 2, and 3. Tehran: Ministry of Education, Centre for the Publication of University Textbooks.

4. Birjandi, P., Maftoon, P., Nikpoor, F., \& Khadir, S. (2011). English 1 and 2-pre-university level. Tehran: Ministry of Education, Centre for the Publication of University Textbooks.

5. Blumberg, R. L. (2008). The invisible obstacle to educational equality: Gender bias in textbooks. Sex Role, 38(3), 345-361.

6. Centre for Women's Participation [CFWP]. (2001). National report on women's status in the Islamic republic of Iran. Tehran: Centre for Women's Participation.

7. Cherland, M. R., \& Harper, H. J. (2007). Advocacy research in literacy education: seeking higher ground. Mahwah, NJ: Lawrence Erlbaum Associates.

8. Davar, Z. (2001). Independence and economic rights of women. In Islamic views on human rights: Viewpoints of Iranian scholars (pp. 209-229) (I. Salami, Trans.). Tehran: Organization for Islamic culture and communications.

9. Davies, B. (1989). Frogs and snails and feminist tales: Preschool children and gender. London: Allen and Unwin.

10. Fairclough, N. (1992). Discourse and social change. London: Polity Press.

11. Fairclough, N. (1995). Critical discourse analysis: The critical study of language. London: Longman.

12. Fairclough, N. (1995). Media discourse. London: Edward Arnold.

13. Fairclough, N. (2001). Language and power (2nd ed.). London: Longman.

14. Fairclough, N., \& Wodak, R. (1997). Critical discourse analysis. In T. A. van Dijk (Ed.), Discourse as social interaction: A multidisciplinary introduction (pp. 258-284). London: Sage Publications.

15. Fast, A. (2010). Iran the people (lands, peoples, and cultures). New York: Crabtree.

16. Ferdows, A. (1994). Gender roles in Iranian school textbooks. In S. K. Farsoun \& M. Mashayekhi (Eds.), Iran: Political culture in the Islamic Republic (pp. 78-90). London: Routledge.

17. Francis, B. (2000). Boys, girls and achievement addressing the classroom issues. London: RoutledgeFalmer.

18. Francoeur, R. (2004). Demographics and a brief historical perspective. In P. E. Drew (Ed.), The continuum complete international encyclopaedia of sexuality (pp. 554-569). New York: The Continuum International.

19. Goddard, A., \& Mean, L. J. (2009). Language and gender. London: Routledge.

20. Haeri, S. (1989). Law of desire: Temporary marriage in Shi'ite Iran (Contemporary issues in the Middle East). Syracuse, NY: Syracuse University Press.

21. Hamdan, S., \& Jalabneh, A. (2009). Topics in EFL textbooks and the question of gender dominance: A case study from public schools of Jordan. The International Journal of Language Society and Culture, 28, 52-56.

22. Hamshari (2012). Allocation of fewer seats to female applicants in medicine, sciences, and technology. Retrieved from http://hamshahrionline.ir/details/53818. July 12, 2012.

23. Higgins, P. J., \& Shoar-Ghaffari, P. (1991). Sex role socialisation in Iranian textbooks. NSWA Journal, 3, 213-232.

24. Holmes, J. (2008). An Introduction to sociolinguistics: Learning about language (3rd ed.). New York: Pearson Longman. 
25. Holmes, J., \& Meyerhoff, M. (2003). Different voices, different views: An introduction to current research in language and gender. In J. Holmes \& M. Meyerhoff (Eds.), The handbook of language and gender (pp. 1-19). Malden, MA: Blackwell.

26. Humm, M. (1996). Equal opportunities and higher education. In L. Morley \& V. Walsh (Eds.), Breaking boundaries: women in higher education (pp. 102-113). London: Taylor \& Francis.

27. Mahmood, K. (2011). Conformity to quality characteristics of textbooks: The illusion of textbook evaluation in Pakistan. Journal of research and Reflections in Education, 5(2), 170-190.

28. Markham, I. S., \& Lohr, C. (2009). A World religions reader (3rd ed.). Malden, MA: Wiley.

29. Mayer, M., \& Wodak, R. (2009). Critical discourse analysis: History agenda theory, and methodology. In R. Wodak \& M. Mayer (Eds.), Methods of critical discourse analysis (pp. 1-34). Thousand Oaks, CA: SAGE.

30. Mehran, G. (2003). Background paper prepared for the education for all global monitoring report 2003/4 gender and education for all: The leap to equality: Gender and education in Iran. Paris: UNESCO.

31. Mir-Hosseini, Z. (2000). Islam and gender. London, New York: I B Tauris.

32. Moghadam, F. (1999). Lifelong learning: New opportunities for women in Muslim country (Iran). Comparative Education, 35, 201-215.

33. Muys, M. (2010). Substance use among migrants: The case of Iranians in Belgium (Criminological studies). Pennsylvania: Asp-Vub Press.

34. Paivandi, S. (2008). Discrimination and intolerance in Iran's textbooks. New York: Freedom house.

35. Pels, T. (2000). Muslim families from Morocco in Netherlands: Gender dynamics and fathers' roles in a context of change. Current Sociology, 48(4), 75-93.

36. Pololi, L. H. (2010). Changing the culture of academic medicine: perspectives of women faculty. Hanover, NH: Dartmouth College Press.

37. Ryan, B. (1992). Feminism and the women's movement: Dynamics of change in social movement ideology and activitism. New York: Routledge.

38. Seidman, S., Fischer, N., \& Meeks, C. (2006). Handbook of the new sexuality studies. London: Routledge.

39. Stange, Z., Oyster, C. K., \& Sloan, J. E. (1996). Encyclopaedia of women in today's world, volume 1. American Ethnologist, 23(1), 61-68.

40. Sunderland, J. (2004). Gendered discourses. Hampshire: Palgrave Macmillan.

41. Tait, R. (2012). Iran Bans Women from College Courses. Daily Telegraph. Retrieved from http:// www.thedailybeast.com/articles/2012/08/21/iran-bans-women-from-college-courses.html.

42. Taxel, J. (1989). Children's literature: A research proposal from the perspective of the sociology of school knowledge. In S. deCastell, A. Luke, \& C. Luke (Eds.), Language, authority, and criticism: Readings in the school textbook (pp. 1-34). London: Falmer Press.

43. Thorne, B., \& Henley, N. (1975). Language and sex: Difference and dominance. Rowley, MA: Newbury House.

44. Touba, J. R. (1987). Cultural effects on sex role images in Elementary schoolbooks in Iran: A content analysis after the revolution. International Journal of Sociology of the Family, 17, 143-158.

45. Vakil, S. (2011). Women and politics in the Islamic republic of Iran: Action and reaction. New York: Continuum.

46. van Dijk, T. A. (2000). Critical discourse analysis. Discourses in Society website. Retrieved from http://www.discourses.org/OldArticles/Critical\%20discourse\%20analysis.pdf.

47. van Dijk, T. A. (2001). New(s) Racism: A discourse analytical approach. In S. Cottle (Ed.), Ethnic minorities in the media: Changing cultural boundaries (pp. 33-49). Milton Keynes: Open University Press.

48. Van Leeuwen, T. (2003). The representation of social actors in discourse. In C. R. Caldas-Coulthard $\&$ M. Coulthard (Eds.), Texts and practices: Readings in critical discourse analysis (pp. 32-70). London: Routledge.

49. Van Leeuwen, T. (2008). Discourse and practice new tools for critical discourse analysis. Oxford: Oxford University Press.

50. Weatherall, A. (2002). Gender, language and discourse. New York: Routledge.

51. Williams, J. (2000). Unbending gender: why family and work conflict and what to do about it. Oxford: Oxford University Press. 
52. Wodak, R. (1997). Gender and discourse. London: Sage.

53. Wodak, R. (2001). What CDA is about: A summary of its history, important concepts and its developments. In R. Wodak \& M. Meyer (Eds.), Methods of critical discourse analysis (pp. 1-13). London: Sage. 